\title{
Uma perspectiva antropológica da crise ecológica e civilizacional
}

\section{The ecological and civilizational crisis from an anthropological perspective}

\author{
Marco Aurélio Bilibio \\ Doutorando no Centro de Desenvolvimento Sustentável/Universidade de Brasília \\ marcoecopsi@gmail.com
}

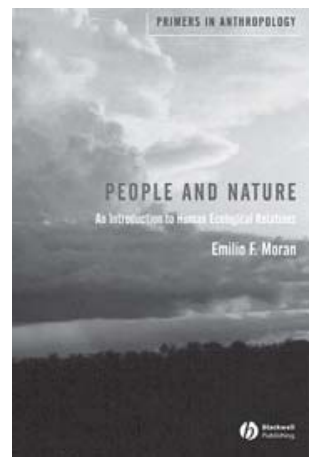

MORAN, Emílio F. People and nature: an introduction to human ecological relations. 2.ed. Malden: Blackwell, 2007. $217 \mathrm{p}$.

$\mathrm{O}$ antropólogo cubano Emilio F. Moran, 62 anos, é professor de antropologia, geografia e ciências ambientais e diretor do Centro Antropológico para Treinamento e Pesquisa em Mudanças Ambientais Globais da Universidade de Indiana, EUA. Doutor em antropologia social pela Universidade da Flórida, foi diretor da seção de Antropologia da Sociedade Americana Para o Avanço da Ciência. Há mais de trinta anos pesquisa os movimentos humanos e mudanças ambientais na Amazônia. Oito de suas 14 obras publicadas em inglês apresentam resultados de suas pesquisas sobre esse tema. Três de suas obras recentes encontram-se disponíveis em português: Ecossistemas florestais (São Paulo, Senac, 2009), Geoinformação e monitoramento ambiental na América (São Paulo, Senac, 2008) e Amazônia: natureza e sociedade em transformação (São Paulo, EdUSP, 2008).

Em seu livro People and nature: an introduction to human ecological relations, Moran se dirige a antropólogos, estudantes e ao público leigo numa obra de fácil leitura, apesar de repleta de informações. ${ }^{1} \mathrm{~A}$ obra pretende situar o leitor numa perspectiva histórica de nossas relações com a natureza, desde as primeiras sociedades nômades de coletores/caçadores até os dias atuais, em que vivemos a ameaça do colapso ecológico, econômico e social por conta de nossas modernas formas de organização.

Para estudantes de antropologia, o livro será de interesse, pois é escrito por um renomado professor e apresenta um quadro da evolução das vertentes pelas quais as pesquisas antropológicas se aproximaram das relações ecológicas entre ser humano e natureza. Porém, será o público leigo o maior beneficiado pela iniciativa de Moran de sair do discurso acadêmico que o notabilizou, porque terá contato com importantes dimensões de nossa história como espécie, desde estratégias de exploração do espaço para segurança alimentar até visões de mundo e valores que asseguraram a nossa sobrevivência. Apesar da fácil leitura e do caráter introdutório, o texto fundamenta-se em farta bibliografia, o que o torna igualmente interessante como fonte de aprofundamento para o leitor avançado. 
A obra tem dois momentos distintos. Na primeira parte, do primeiro ao penúltimo capítulo, Moran descreve a nossa caminhada evolutiva até nossos dias. Mas no último capítulo o leitor se surpreenderá com a mudança de tom e encontrará um autor apaixonado e comprometido com a vida e com nosso futuro, tocando abertamente nos pontos sensíveis da construção cultural que nos levou ao atual impasse e propondo saídas radicais.

As contribuições das ciências humanas, como antropologia, psicologia e sociologia, são de grande importância para clarear as muitas dimensões do impasse civilizatório gerado pelas mudanças climáticas. Moran esclarece as formas como nós sempre manipulamos o meio para nossos próprios fins. Contudo, nossas sociedades ancestrais o fizeram de forma a garantir a reciprocidade entre espécies. Essas comunidades tinham no mito uma lógica circular que as nutria com os significados, muitas vezes religiosos, necessários à sua sobrevivência. A lógica linear moderna, centrada na relação custo-benefício, nos faz estabelecer relações muito diferentes com o meio, em que estão ausentes as salvaguardas culturais que asseguravam àqueles povos relações de baixíssimo impacto sobre o meio e alta qualidade ecológica, baseadas em conhecimentos tradicionais que estão igualmente se perdendo por serem considerados atrasados pela mentalidade de mercado. Nos últimos cinquenta anos, o consumo se tornou parte inerente da nossa forma de dar sentido à vida. O contraste é imenso em relação a quem éramos. Atualmente o que uma pessoa tem faz parte e molda a maneira como ela se vê. A evolução na direção do consumo como base da sociedade é apontada por Moran como um dos grandes diferenciais históricos de nossa civilização moderna e, seguramente, o ponto em que nosso futuro sobre o planeta começou a ser estrangulado.

O livro dirige-se para um diagnóstico histórico e subjetivo da crise, ao apontar seus dois momentos fundantes: a Revolução Industrial, início de uma nova relação com os recursos naturais; e o pós-guerra, início da era do consumo acelerado. O autor, no entanto, esquece da importante contribuição de Lynn White (1996) sobre a influência religiosa na mudança de mentalidade, que rompeu com os laços ecológicos entre seres humanos e natureza e os colocou na rota de colisão que agora é evidente. Apesar disso, o tema não lhe passa despercebido, pois assinala o drama de nações como a Índia, que em breve se tornará o país mais populoso do mundo e vive a ambiguidade de inserir-se agressivamente na sociedade de mercado-consumo tendo como background uma religiosidade essencialmente biocêntrica. Uma revalorização das tradições biocêntricas, em consonância com fundamentos da ecologia profunda, poderia ser um contraponto à tendência consumista que está esgotando os recursos naturais. Escolas, igrejas, indivíduos e organizações teriam um importante papel a cumprir na reavaliação geral das premissas de nossa cultura consumista.

No capítulo final, Moran nos insufla a profundas revisões interiores e exteriores, que vão desde o sentido de vida que deriva da sociedade de consumo à qualidade das relações familiares em face do consumo e da mídia. Abandona a frieza acadêmica, que em muitos pontos do livro está presente e assume posição radical e orientadora, dando à obra um caráter crítico e orientado ao biocentrismo. O autor pretende oferecer saídas a partir de seu olhar antropológico. O tema da mídia, em especial, recebe dele duras e acertadas críticas, por ter se tornado veículo do consumismo e gerado modelos de comportamento coerentes 
com aqueles desejados pelo mercado. Moran afirma que indivíduos e organizações devem andar juntos para gerar mudanças institucionais por meio da revisão de prioridades, da correta definição de preços que incorporem os serviços ambientais suprimidos pelo produto e da reconstrução da confiança e do senso de comunidade. Assumindo uma postura de ruptura, Moran pergunta a si mesmo: não seria isso ruim para a economia global? Sim, seria muito ruim para a economia do business-as-usual, mas como o 'as usual' se tornou inviável, seria muito bom para o planeta.

Afirma o autor que sempre existiu um grande medo, nos centros da economia global, quanto ao potencial subversivo da visão ecológica. Ele justifica esse medo unindo perspectiva histórica e análise crítica, que apontam as origens antropológicas das mudanças climáticas e as conectam com os dogmas atuais de nossa economia. O que está em xeque é a noção de ser humano desejável pelo mercado, e a superação dessa noção é nosso grande desafio. Não leia esse livro se estiver confortável com o que está acontecendo nesses anos provavelmente decisivos para nosso futuro. Mas não deixe de lê-lo se quiser fazer algo a respeito.

\section{NOTA}

${ }^{1}$ No Brasil, o livro foi publicado com o título Nós e a natureza: uma introdução às relações homem-ambiente (São Paulo, Senac, 2008), impresso em papel reciclado e com excelente índice remissivo, gráficos, tabelas e figuras, mas sem as fotografias presentes na edição original.

\section{REFERÊNCIA}

WHITE, Lynn.

The historical roots of our ecological crises. In: Gottlieb, Roger (Ed.). This sacred Earth: religion, nature and environment. New York: Routledge. 1996. 